No account of the physical chemistry summer school at Cambridge would be complete without some reference to the happy human relationships which were established, and in many cases strengthened, between academic research workers and industrial research workers, and between British scientists and foreign scientists. Politicians have yet to learn that scientists are men who are kindly disposed towards one another, have a common faith and interest in their subject and desire nothing more than freedom to study Nature and to subjugate her to the benefit of mankind. A gathering of this kind can be lightly described as just another conference, conducted with evident pleasure, and not unprofitably. On the other hand, its consequences are incalculable. To bring industrial and academic research workers together is a vital step in furthering the national economy. To bring foreign scientists from all over the world-including that part which lies beyond the 'iron curtain'-into harmonious contact with British scientists is to increase the volume of international goodwill, in an age when that commodity is none too abundant, and when the contribution of the scientists to it is paramount.

E. A. Moelwyn-Hughes

\section{GLAZED FROST IN ENGLAND OF JANUARY 1940}

CLAZED frost, the phenomenon of rain or drizzle $\checkmark$ falling on a frozen earth and covering every. thing with a layer of clear ice, is not of very frequent occurrence in Britain and, when it does occur, it is usually short-lived and quickly followed by an influx of air warm enough to melt the ice. In the United States it is sufficiently common and severe to be called an ice storm. The main economic effects are severe disturbance of transport by the very slippery roads and paths and destruction of overhead telegraph and power lines. The precipitation falls from clouds at a temperature above freezing point through a low-lying layer of air at a temperature below freezing point. The supercooled droplets freeze on striking the ground, trees, telegraph wires and so on, forming a coating of clear slippery ice. Usually the phenomenon is transitory because it is produced by the fairly fast-moving warm front or warm occlusion of a winter depression.

During January 25-February 4, 1940, however, as is described by Dr. C. E. P. Brooks and Mr. C. K. M. Douglas in Geophysical Memoir No. 98 of the Meteorological Office, encitled "Glazed Frost of January 1940"*, intense persistent glazed frost formed over much of England south of a line from the Humber to the Mersey except East Anglia. It was especially intense along a wide belt from North Wales to Kent. The ice formed cylinders up to $2 \frac{1}{2}$ in. in diameter on telegraph wires, twigs, etc., and a coating an inch thick on the ground. Telegraph poles and trees collapsed in large numbers under the weight of the ice. The memoir contains some vivid photographs of the ice which the authors describe as probably unequalled, certainly in at least a century, for extent and persistence in Great Britain.

The meteorological circumstances producing the ice are fully described. At the time there was an anticyclone over Scandinavia and a depression south-

* Air Ministry : Meteorological Office. Geophysical Memoir No. 98: Glazed Frost of January 1940. By Dr. C. H. P. Brooks and C. K. M. Douglas. Pp. $40+$
1956.) 78. 6 d. net. west of Iceland. Between these systems a very cold south-easterly wind blew across most of the British Isles with temperatures between $25^{\circ}$ and $30^{\circ} \mathrm{F}$. inland. Two warm fronts moved successively early in the period from the south-west across Ireland, south-west England and Wales and then oscillated slowly backwards and forwards over the mouth of the Channel and south-west England, bringing the rain which fell through the cold surface air to produce the glazed frost. Finally, on February 3, the warm air swept northwards, displacing the cold south. easterly current over the country and melting all the ice. The chief technical meteorological interest lies in the motion of the fronts, which over a considerable period departed widely from that given by the components of geostrophic wind normal to them.

The differences were abnormally large. One warm front over south-west England on January 28, which should, on the geostrophic basis, have moved at the rate of $15 \mathrm{~m} . \mathrm{p} . \mathrm{h}$. to the north-east, moved at $5 \mathrm{~m} . \mathrm{p} . \mathrm{h}$. south-west. The differences between actual and geostrophic wind are too large to be accounted for by accelerations associated with pressure changes, and the best suggestion is that of a departure caused by turbulent friction in the frontal zone in which the wind changed rapidly in direction. This friction introduces a term in the hydrodynamic equations proportional to the coefficient of turbulence, multiplying the second differential coefficient with respect to height of the wind component parallel to the front. It is shown in the memoir that this would have the right order of magnitude.

\section{THE BUKIDNON OF MINDANAO}

DROF. FAY-COOPER COLE'S recent field-work monograph on the people of one of the larger islands of the Philippines, entitled "The Bukidnon of Mindanao"*, is an unusual publication. Had it been written by an anthropologist as a result of recent field-work, it is doubtful whether there would have been any justification for having it published. But the field-work dates from 1910, and the author is a professor of anthropology (emeritus) writing in 1956. The situation has its possibilities, and on commencing to read the monograph one wonders whether the author will succeed in producing a work of contemporary interest on foundations that are left over from a different period. The answer is, unfortunately, no.

It would, of course, be unfair to take the author to task for not having had 1956 in mind in 1910; but it is obviously true that he has been unable to decide what to do with the material himself, and, as a result, the book is concerned with everything in general, but nothing in particular. There are good illustrations of material objects, houses and dress, all of which are interesting, but within the scope of a hundred-odd pages the text rushes through chapters with such diverse titles as "Making a Living" ; "The Life Cycle, Social and Political Organization"; "The Spirit World" ; "The Ceremonies" ; "Music and Dancing"; "Celestial Bodies"; "Stories and Legends".

Prof. Cole seems to have had no concern for kinship, at least in 1910 -which is a pity; for the Bukidnon appear to have a system of bilateral kinship on the Iban pattern, but there are scarcely

*Fieldiana: Anthropology. Vol. 46: "The Bukidnon of Mindanao". By Prof. Fay-Cooper Cole. Pp. 140. (Chicago: Chicago Natural History Museum, 1956.) 4 dollars. 
any asides in that direction. The remarks on marriage are more tantalizing than illuminating, and social and political organization-including such headings as crime and law (four paragraphs) and slavery (two paragraphs)-merits only ten pages.

It is not that the author has no interest in the problems of social anthropology; for example, he reports the notable phenomenon-recorded also in other areas-that as the "aggressive intervention" (sic) of the authorities (in this case the American Governor) increased in the daily life of the people, and as they were forcefully moved into "model villages", there was a "withdrawal into the old ways in religion". With the decline of the political importance of the local headmen, the influence of the "mediums" and their ceremonies became more powerful "to the extent that they dominated the social and religious life" of the Bukidnon. But all this is merely stated and not followed up. There are, instead, descriptions of ceremonies concerned with ritual healing and with the fertility of the crops, and there are discussions on the concepts of the supernatural. However, the author seems to have worked through interpreters, and what with the unclear social background and without the backbone of a theory to give the material some coherence, these pages remain unrewarding.

The conclusion strikes a different vein. For, when the author is left with two pages, he revoals that he had in mind all the time "the attempt to account for the peopling of Central and Southern Mindanao": this aim is certainly not disclosed earlier on, nor is it pursued with much vigour.

NUR YaLMaN

\section{VOLTA RIVER PROJECT IN THE GOLD COAST}

$\mathrm{T}$ HE report of the preparatory commission on the Volta River Project set up in 1953 by the United Kingdom and Gold Coast Governments was pub. lished on July 27 as a non-parliamentary paper, and the Secretary of State for the Colonies, Mr. A. T. Lennox-Boyd, said in a written answer in the House of Commons on that day that the report provides evidence of an extremely thorough examination of all the problems to be solved in a project of this magnitude. The main conclusions of the commission are that the project is technically sound and could be carried out successfully; it is not capable of significant improvement from an economic point of view, but the greatest return would be derived by achieving maximum production as soon as possible. The commission further concludes that the project should be competitive in relation to other schemes, provided that the time-table of construction is observed, a sound policy adopted in the employment and provision of living conditions for the labour force, economic stability maintained in the Gold Coast, and that the aluminium companies are satisfied that the internal cost of operating the smelter would be acceptable. The report also considers such factors as the co-ordination of the future development plans of the Gold Coast Government, the maintenance of adequate administrative and technical services, and the level of future world demand for aluminium and future developments in the generation of power from nuclear energy.

As a result of its investigations, the commission considers that the scheme, based on two stages of aluminium production, would cost $£ 184.9$ million (with a capacity of 120,000 tons a year), rising to a total of $£ 231 \cdot 3$ million (with a capacity of 210,000 tons a year) compared with the estimates of $£ 116$ million and $£ 144$ million in 1952 but including also certain additional work. The commission suggests that it would be prudent to allow for a further increase of 40-50 per cent so as to obtain a realistic appreciation of the finances that might be required for the project, which would take about eight years to bring to production. This increase should not make the project less attractive provided world prices move upwards at roughly the same rate. The United Kingdom and the Gold Coast Governments and the aluminium companies have each re-affirmed their interest in the project, though none of them is yet committed to participation. They have agreed that, because of the substantial increase in the estimated capital cost, it is necessary to review both the framework and the method of finance; as the next step, the International Bank is being asked to make a general assessment of the project and to indicate the extent to which it would be willing, in principle, to participate if the two Governments and the aluminium companies reached agreement on the fræmework.

\section{POLLEN CHEMISTRY}

$\mathrm{R}$ LUNDEN, with the citation of some eighty. one references, has given a useful résumé of the literature of pollen chemistry (Grana Palynologica, 1 , No. 2,$3 ; 1956$ ). The protein and amino-acid content of different pollen grains has long been of special interest and practical importance, on one hand, to apiarists in search of a pollen substitute in the rearing of bees, and, on the other, to medical investigators interested in the active principle in pollen allergy.

With the development of partition chromatography, considerable advances are now being made in ascertaining both qualitative and quantitative facts regarding the amino-acid content of grains; indeed, all the common amino-acids have now been found to be present in pollens, either bound to protein or in the free state, though some important deficiencies have been reported. As the carbohydrate content of pollen grains is considered to be of less importance from the point of view of bee nutrition, this aspect of pollen chemistry has received rather less attention; but analytical data have been given for the starch, cellulose, pentosan and reducing sugar contents of the pollen of a number of species. Lipides have also been examined.

Studies of the vitamins and hormones of pollen grains have shown that, in general, they are rich in the vitamins of the $B$ group but low in fat-soluble vitamins; some quantitative information relating to a considerable number of vitamins is now available for several species. The evidence indicates pollen to be an exceptionally good source of watersoluble vitamins, for example, of thiamine, riboflavin, pantothenic acid, nicotinic acid and ascorbic acid. Estrogenic substances have been detected in certain pollens, and also plant growth regulating substances. Pollen enzyme chemistry likewise promises to be a particularly rich field for research. Reference is also made to the pigments, which are chiefly flavonols and carotenoids, and to the inorganic and various miscellaneous constituents. 